\title{
Prevalence of anti-nuclear autoantibodies (ANA) in the general Polish population - analysis of the influence of sex and age on the variability of ANA.
}

Paweł Krzemień ( $\nabla$ p.krzemien@euroimmun.pl)

Medical University of Silesia: Slaski Uniwersytet Medyczny w Katowicach https://orcid.org/0000-00028198-208X

\section{Sławomir Kasperczyk}

Medical University of Silesia: Slaski Uniwersytet Medyczny w Katowicach

\section{Maciej Banach}

Medical University of Lodz: Uniwersytet Medyczny w Lodzi

\section{Aleksandra Kasperczyk}

Medical University of Silesia: Slaski Uniwersytet Medyczny w Katowicach

\section{Michał Dobrakowski}

Medical University of Silesia: Slaski Uniwersytet Medyczny w Katowicach

\section{Tomasz Tomasik}

Jagiellonian University Medical College Faculty of Medicine: Uniwersytet Jagiellonski Collegium Medicum Wydzial Lekarski

\section{Adam Windak}

Jagiellonian University Medical College Faculty of Medicine: Uniwersytet Jagiellonski Collegium Medicum Wydzial Lekarski

\section{Mirosław Mastej}

Mastej Medical Center

\section{Alberico Catapano}

Politecnico di Milano

\section{Kausik K Ray}

Imperial College London

\section{Dimitri P Mikhailidis}

University College London

\section{Peter P Toth}

JHU School of Medicine: Johns Hopkins University School of Medicine

\section{George Howard}

\section{Alabama Public Health: Alabama Department of Public Health}

\section{Gregory H Lip}

Johns Hopkins School of Medicine: Johns Hopkins University School of Medicine 


\section{Maciej Tomaszewski}

University of Manchester School of Medicine: The University of Manchester Faculty of Biology Medicine and Health

\section{Fadi J Charchar}

Federation University Australia

\section{Naveed Sattar}

University of Glasgow

\section{Bryan Williams}

University College London

\section{Thomas M MacDonald}

University of Dundee

\section{Peter E Penson}

Liverpool John Moores University - City Campus: Liverpool John Moores University

Jacek J Jóźwiak

Opole University: Uniwersytet Opolski

\section{Research article}

Keywords: antinuclear antibodies, ANA, prevalence, indirect immunofluorescence assay, IIFA, gender, age, cut-off threshold

Posted Date: April 13th, 2021

DOI: https://doi.org/10.21203/rs.3.rs-395341/v1

License: () (1) This work is licensed under a Creative Commons Attribution 4.0 International License. Read Full License 
Prevalence of anti-nuclear autoantibodies (ANA) in the general Polish population analysis of the influence of sex and age on the variability of ANA.

Paweł Krzemień ${ }^{1 *}$, Sławomir Kasperczyk ${ }^{2}$, Maciej Banach ${ }^{3 *}$, Aleksandra Kasperczyk ${ }^{2}$, Michał Dobrakowski², Tomasz Tomasik ${ }^{4}$, Adam Windak ${ }^{4}$, Mirosław Mastej ${ }^{5}$, Alberico Catapano $^{6}$, Kausik K. Ray ${ }^{7}$, Dimitri P. Mikhailidis ${ }^{8}$, Peter P. Toth ${ }^{9}$, George Howard ${ }^{10}$, Greory Y. H. Lip ${ }^{11}$, Maciej Tomaszewski ${ }^{12}$, Fadi J. Charchar ${ }^{13}$, Naveed Sattar ${ }^{14}$, Bryan Williams ${ }^{15}$, Thomas M. MacDonald ${ }^{16}$, Peter E. Penson ${ }^{17}$, Jacek J. Jóźwiak ${ }^{18}$ on behalf of the LIPIDOGRAM2015 Investigators**

1. Euroimmun Polska Sp. z o.o., Poland

2. Department of Biochemistry, Faculty of Medical Sciences in Zabrze, Medical University of Silesia, Katowice, Poland.

3. Department of Hypertension, Medical University of Lodz, Łódź, Poland

4. Department of Family Medicine, Jagiellonian University Medical College, Krakow, Poland 5. Mastej Medical Center, Jasło, Poland

6. Department of Pharmacological Sciences University of Milano and Multimedica IRCCS, Milano Italy

7. Imperial Centre for Cardiovascular Disease Prevention, Department of Primary Care and Public Health, Imperial College, Kensington, London, UK

8. Department of Clinical Biochemistry, Royal Free Hospital, University College London, London, UK

9. Cicarrone Center for the Prevention of Cardiovascular Disease, Johns Hopkins University School of Medicine, Baltimore, Maryland and CGH Medical Center, Sterling, Illinois, USA 
10. Department of Biostatistics, School of Public Health of Alabama at Birmingham, AL, USA 11. Liverpool Centre for Cardiovascular Science, University of Liverpool and Liverpool Heart \& Chest Hospital, Liverpool, United Kingdom; and Department of Clinical Medicine, Aalborg University, Aalborg, Denmark

12. Division of Cardiovascular Sciences, Faculty of Biology, Medicine and Health, University of Manchester, UK

13. School of Health and Life Sciences, Federation University Australia, Ballarat, Victoria, Australia

14. Institute of Cardiovascular and Medical Science, University of Glasgow, Glasgow, UK

15. NIHR University College London Biomedical Research Centre, University College London and University College London Hospitals NHS Foundation Trust, London, UK

16. MEMO Research, University of Dundee, Ninewells Hospital and Medical School, Dundee DD1 9SY, UK

17. School of Pharmacy and Biomolecular Sciences, Liverpool John Moores University, Liverpool, UK; and Liverpool Centre for Cardiovascular Science, Liverpool, UK

18. Department of Family Medicine and Public Health, Faculty of Medicine, University of Opole, Opole, Poland

\section{*Corresponding authors:}

- Pawel Krzemień, MSc, Euroimmun Polska Sp. z o.o., 2a Widna St., 50-543 Wroclaw, Poland. Phone: +48 509657 480; Fax: +48 713730011 ; E-mail: pjkrzemien@gmail.com 
- Prof. Maciej Banach, MD, PhD, FNLA, FAHA, FESC, FASA, President, International Lipid Expert Panel (ILEP) \& Head of Department of Hypertension, Medical University of Lodz, 281/289 Rzgowska St., 93-338 Lodz, Poland. Phone: +48 4227111 79; Fax: +48 4227115 60; E-mail: maciejbanach77@gmail.com

Word count: 2634 (without tables, figures and references)

Number of tables: 5

Number of figures: 1 


\section{ABSTRACT}

Objectives: Diagnosis of Systemic Autoimmune Rheumatic Diseases using antinuclear autoantibodies (ANA) is dependent on many factors and varies between populations, such that the screening dilution used for indirect immunofluorescence assay (IIFA) should be defined locally for each population. The aim of the study was firstly, to assess the prevalence of ANA in the Polish adult population depending on age, sex and the cut-off threshold used for the results obtained. Second, we estimated the occurrence of individual types of ANA staining patterns.

Methods: The tested material included serum samples from 1731 participants (1043 women and 688 men) that were tested with the commercially available IIFA using two cut-off thresholds $1: 100$ and $1: 160$.

Results: We found ANA in 260 participants (15.0\%), but the percentage of positive results strongly depended on the cut-off level. For a cut-off threshold 1:100, the positive population was $19.5 \%$ and for the $1: 160$ cut-off threshold, it was $11.7 \%$. The most prevalent ANA staining pattern was AC-2 Dense Fine speckled (50\%), followed by AC-21 Reticular/AMA (14.38\%) ANA were more common in women (72\%); 64\% of ANA positive patients were over 50 years of age.

Conclusion: ANA prevalence in the Polish population is at a level observed in other highly developed countries. ANA were more prevalent in women and elderly individuals. In order to reduce the number of positive results released, we suggest that Polish laboratories should set $1: 160$ as the cut-off threshold.

Keywords: antinuclear antibodies, ANA, prevalence, indirect immunofluorescence assay, IIFA, gender, age, cut-off threshold

\section{Abstract - word count: 246}




\section{BACKGROUND}

Autoimmune diseases $(\mathrm{AD})$ are characterized by immune responses to self-antigens resulting in tissue damage or dysfunction. The response can be systemic or can affect specific organs or body systems[1]. AD include more than 80 diseases, of which systemic autoimmune rheumatic diseases (SARDs) are a particular group, with a very diverse clinical picture and complex pathogenetic mechanisms[1]. It is well known that SARDs mainly affect older people, and predominantly women[2-5]. At the same time, there are increasing cases of connective tissue diseases in young people and even in children[6-8]. Thus far, the etiology of anti-nuclear antibody (ANA) formation has not been fully elucidated. There are many suspected factors that increase the risk of ANA biogenesis and occurrence, including genetic predisposition and environmental factors such as infections, oxidative stress factors, physical and chemical agents, as well as stressful life events[4,5,9-11].

Laboratory diagnosis of SARDs is complicated by the requirement for specialized tests to enable detection of autoantibodies. For years, the indirect immunofluorescence assay (IIFA) has been regarded as the gold standard for measuring ANA. According to current recommendations, the human laryngeal carcinoma cell line (HEp-2) is a recommended substrate for detecting ANA, and each positive test result should include an estimated titer and fluorescence pattern[6]. The current recommendation for a positive ANA finding is a titer of $\geq 1: 160[6]$. However, the IIFA assay ANA threshold titer is dependent on reagents, equipment and other local factors, and hence the screening dilution should be defined locally.

A main feature of the screening test should be high sensitivity (which significantly reduces its specificity, i.e. the number of false-positive results increases - positive results are also obtained in people without symptoms of rheumatic disease)[12]. This means that the higher the antibody titer, the greater the likelihood that the result is clinically relevant and is associated with symptoms. Up to $12.9 \%$ healthy individuals observed at 1:80 dilution are ANA positive, 
and $90.2 \%$ of clinically diagnosed as SARDs patients are also positive[13]. The ANA titer is higher in patients with SARDs than in healthy individuals[13]. Biological autoimmunity is not always pathological and can be observed in healthy people. Naturally circulating antibodies in normal human sera can recognize various substances, including self-antigens, but with a low avidity. That's why they are natural autoantibodies (NAAbs) $[14,15]$.

Chronic activation of the immune system can lead to expansion of naturally present autopolyreactive clones of lymphocytes B and, in genetically predisposed individuals, can lead to the development of autoimmune diseases[16,17]. The prevalence of autoantibodies in the general population is common and is estimated to be between 5.92 and $30.8 \%$ with a lower prevalence in the Chinese population and a higher prevalence in the Afro-American population, but it is worth pointing out that differences in the cut-off thresholds used in the studies are the cause of this wide range $[2,4,18-23]$.

The aim of this study was firstly to assess the prevalence of ANA in the Polish population, taking into account age, sex and the cut-off threshold used for the results obtained. Second, we estimated the occurrence of individual types of ANA staining patterns. As far as we are aware, similar large cohort population studies have not yet been conducted in the Polish population.

\section{MATHERIALS AND METHODS}

\section{Design}

A nationwide observational, cross-sectional study was carried out in Poland in the fourth quarter of 2015 and the first and second quarters of 2016.

\section{Sampling}

This study is part of a large research program "Nationwide study of cardiovascular health in primary care in Poland - LIPIDOGRAM2015 and LIPIDOGEN2015", the design and rationale of which have been described in detail previously[24]. Briefly, the recruitment was 
carried out by 438 primary care physicians in 16 major administrative regions of Poland. Physicians/investigators were randomly selected from the Medical Data Management database. The expected number of patients recruited for LIPIDOGRAM2015 study (consecutive sample) was 13,000 - 14,000 with $13-15 \%(1,700$ - 2,000) enrolled to the LIPIDOGEN2015 sub study (random sample). The program covered only adult patients over 18 years old. Each patient had to complete a questionnaire concerning medical and family history, concomitant diseases, and pharmacotherapy. Anthropometric measurements (height, body weight, waist circumference, and hip circumference) were performed at the doctor's office. In all enrolled patients, serum samples were obtained after $\geq 12 \mathrm{~h}$ of fasting. On the same day, measurements of blood pressure, heart rate, and fasting glucose were obtained as well as lipid profile samples. For the LIPIDOGEN2015 sub-study, saliva samples for DNA isolation and blood samples for measurement of glycated hemoglobin, oxidative stress parameters, autoantibody levels, and inflammatory cytokine profile and apolipoprotein profile were collected.

For this study we used 1731 serum samples from the abovementioned LIPIDOGEN2015 sub-study. The tested group included 1043 women and 688 men. The blood samples were transferred in cooled containers $\left(-20^{\circ} \mathrm{C}\right)$ to a central laboratory (Silesian Analytical Laboratories - SLA in Katowice, Poland) for biochemical analyses and then to the autoimmune laboratory (Euroimmun Poland Ltd. Customer Training Laboratory in Wroclaw, Poland) for ANA determination.

\section{Laboratory analyses of $A N A$}

ANA were detected by a IIFA using human laryngeal carcinoma cells (HEp-2) with commercially available Euroimmun Medizinische Labordiagnostika AG (Lübeck, Germany) test kits Mosaic Basic Profile 3 (catalogue number FC 1800-2010-3). Sample incubation was carried out manually, according to the instructions provided by the manufacturer of the test, except that 998 samples were diluted with a threshold cut-off 1:160 as recommended by the 
current guidelines[6] and 733 patient samples were diluted with a threshold cut-off 1:100 as recommended by the manufacturer's instruction. The samples were divided into two groups randomly. The results were evaluated on a EUROstar III fluorescence microscope (CarlZeiss Oberkochen, Germany). The test result included a qualitative assessment of the presence of ANA, estimation of antibody titer, and determination of the characteristic pattern according to the International Consensus on ANA patterns (ICAP) nomenclature[25]. The results from IIFA were collected and stored as digital images.

\section{Statistical analysis}

Statistical analyses was carried out were performed using Statistica 13.3 (StatSoft, Tulsa, USA). Data are expressed as mean \pm SD (for normal distribution) and median (nonparametric distribution) for continuous variables, and as a percentage for categorical variables. Univariate comparison of markers related to autoimmune diseases according to clinical variables was performed using the U-Mann-Whitney method for nonparametric variables or $\chi^{2}$ test/Fisher exact test where appropriate. A two-sided $\mathrm{p}<0.05$ was considered to indicate significance.

\section{Ethical approval}

The study was performed in accordance with principals outlined in Declaration of Helsinki. Every patient gave a written informed consent to participate. The study was approved by the Bioethical Committee of the Chamber of Physicians (No.K.B.Cz.-0018/2015).

\section{RESULTS}

The study included 1731 patients attending primary health care practices (1043 women and 688 men). 1098 people were diagnosed with hypertension, coronary artery disease, dyslipidemia, diabetes, atrial fibrillation, kidney disease or stroke. 649 people were apparently 
healthy individuals. The mean age of participants was $51 \pm$ (SD 13 years) and $60.25 \%$ were female (Table 1). The body mass index (BMI) indicated that the participants were on average slightly overweight [26], and the average waist-hip ratio (WHR) was above the normal range for both men and women[27].

The ANA test was positive in 260 patients (15.0\%) of the entire study population. Of the 733 participants for whom a cut-off threshold of $1: 100$ was used, $19.5 \%(n=143)$ had a positive result for ANA. Only 27 patients in this group had titers higher than 1:100. In the second group, consisting of 998 participants with a 1:160 cut-off threshold, the percentage of ANA positive results was clearly lower, at $11.7 \%(\mathrm{n}=117) .32$ patients in this group had titers higher than $1: 160$. Frequency analysis comparing the $1: 100$ and $1: 160$ groups in terms of final ANA titer is shown in Figure 1. ANA staining patterns corresponding to ICAP are in Table 2. We present summary data for both subgroups because the cut-off titer used did not significantly affect the distribution of detected types of staining. The most frequent ANA staining pattern was AC-2 Dense Fine speckled (50\%) followed by AC-21 Reticular/AMA (14.4\%) and AC4/AC5 Fine/Large/Coarse Speckled (14.6\%).

The relationship between sex and the occurrence of autoantibodies is shown in Table 3. In the tested group, ANA antibodies are more often detected in women than in men but the difference was less obviously distinct at higher titers $\geq 1: 640$. In general, there were no significant differences in the types of patterns detected for both genders, except AC4/AC5 $(p=0.001)$ and AC-2 $(p<0.001)$ which were detected more often in women than in men. Nucleolar type of staining AC-9/AC-10 ( $\mathrm{p}=0.022)$ was more often detected in men.

Characteristics of the participants based on the occurrence of ANA are presented in Table 4. which shows that ANA were detected more often in women than in men ( $72 \%$ vs. $28 \%)$ $(p<0.001)$. No correlation was found between the occurrence of autoantibodies and broader cardiovascular disease and lipid disorders. Autoantibodies were more frequently detected in the 
elderly $(\mathrm{p}<0.001)$ - Table 4 , differences for individual age ranges are shown in Table 5 . In the entire studied population, the lowest percentage of ANA positive individuals was observed in those under 30 years of age (7.9\%), and the highest proportions of ANA positive people were in those aged $60-70(20.6 \%)$ and over 70 years $(22.4 \%) .84 \%$ of ANA positive individuals were over $40(n=219)$ and $64 \%$ were over 50 years of age $(n=167)$.

\section{DISCUSSION}

In our study, the prevalence of ANA in the Polish population was $15 \%$, similar to results observed in other developed countries. However, it is worth remembering that the percentage of positive results is strongly dependent on the cut-off threshold used. Therefore, to reduce the number of positive results released by Polish laboratories, we suggest that a serum dilution of 1:160 be used for screening purposes, especially since it is very rare for individuals with lower ANA titers to have clinical symptoms[13,21]. However, the promulgation of official recommendations requires additional studies supported by data on diagnostic sensitivity and specificity in a group of patients diagnosed with SARD. Therefore, this proposal should not be considered as an official recommendation to laboratories.

The prevalence of ANA in the general population is common and, depending on the cutoff threshold used by investigators, can reach up to $30.8 \%$.[23]. The aim of the present study was to determine the prevalence of ANA in a general Polish population based upon on the cutoff threshold used and the influence of patient sex and age on the results. A total of 1731 samples were tested, and ANA antibodies were detected in $15 \%$. This result does not differ from the results obtained by other researchers using a similar level of cut-off thresholds e.g. in the previously mentioned studies of Maritz et al. ANAs were present in $12.9 \%$ of healthy individuals at a 1:80 cut-off titer[13]. Similar results were obtained by Prüßmann et al. who tested over 5000 healthy blood donors among which $17.7 \%$ were ANA positive[19] and Agmon-Levin et al. who reported $13.3 \%$ at the 1:80 cut-off titer[6]. ANA prevalence in the 
U.S. population aged $\geq 12$ years was also similar at $13.8 \%$ (titer $\geq 1: 80)[20]$. A higher percentage of ANA was observed by Akmatov, et al. in Germany, in which the general population was found to be positive for ANA in $33.3 \%$ of individuals (titer $\geq 1: 80$ ) and $28.6 \%$ with a titer of $1: 80$ or $1: 160[4]$.

The influence of the cut-off threshold used on the percentage of positive results is obvious. Therefore, our study assessed the impact of the initial cut-off dilution used in the Polish population on the number of positive results obtained. In order to assess the impact, the test group was divided into two subgroups. In the first group we used the cut-off threshold 1:100 recommended by the test manufacturer. At this cut-off in the examined group of 733 samples, a positive result was observed in 19.5\%. A 1:160 cut-off threshold, which is often found to be the most suitable for the evaluation of adult patients[6] was used in the second subgroup where the percentage of ANA positive results was lower, at 11.7\%. This downward has been observed in previous studies[4].

Low antibody titers are usually not clinically relevant and are rarely accompanied by clinical symptoms. At the same time there is an increased likelihood of SARDs with higher ANA titer[4,8]. Indeed, $13.5 \%$ of our participants had a titer of 1:320, $6.45 \%$ titer $1: 640$ and $2.69 \% \geq 1: 1000$, and these individuals may be at higher risk of developing or suffering from SARDs.

As reported by Satoh et al. in ANA-positive individuals, nuclear patterns were seen in $84.6 \%$, cytoplasmic patterns in $21.8 \%$, and nucleolar patterns in $6.1 \%[20]$. Our results appear to show that according to the ICAP classification, nuclear staining was observed in $77 \%$, cytoplasmic patterns in $20.6 \%$ and mitotic in $2.5 \%$. The most frequent ANA staining pattern was AC-2 dense fine speckled (50\%) followed by AC-21 Reticular/AMA (15.38\%) and AC4/AC5 - Fine/Large/Coarse Speckled (14.62\%). The dense fine speckled pattern (AC-2) is associated with apparently healthy individuals, but this association only holds if the specificity 
is confirmed as monospecific for DFS70 because the pattern recognized as AC-2 is not always induced by anti-DFS70 antibodies[28]. Miyara et al. showed also that the likelihood of antiDFS70 antibodies is significantly lower than in patients with other IIFA patterns[29]. Due to the fact that the AC-2 pattern was detected in half of the samples tested, an interesting issue requiring further testing would be an assessment of the prevalence of anti-DFS70 antibodies in the Polish population.

As mentioned, there were no significant differences for the types of pattern staining by gender except AC4/AC5 and AC-2 which were detected more often in women than in men. In contrast, nucleolar type of staining AC-9/AC-10 were more often detected in men.

It would be useful to link these data with information about the incidence of individual connective tissue diseases. Unfortunately, the survey completed by patients participating in the LIPIDOGRAM2015 \& LIPIDOGEN2015 project did not include questions about SARDs. Furthermore, there are no relevant statistical surveys for the Polish population[30]. Among ANA positive individuals there was a clear predominance of women over men, consistent with other worldwide observations[3,5,20].

In the studied group, the percentage of ANA positive people in the Polish population increased with age, however, a detailed analysis does not show a clear upward trend if we compare subsequent age groups divided into 10-year age ranges. At all age ranges, the percentage of ANA positive women is greater than men. In total $84 \%$ of ANA positive patients were over 40 and $64 \%$ over 50 years of age, which is not surprising given the impact of the age on the likelihood of autoantibodies. Surprisingly, there was no clear upward trend in the percentage of ANA positive people in the next 10-year age ranges from 30-60 years. The percentage of positive results remains at $13.4-13.7 \%$. 
Most people with a positive ANA are not diagnosed with autoimmune disease, and the probability of future disease is low[21] but, as shown by Jonsson, R. et al. sometimes the production of specific autoantibodies $(\mathrm{AAb})$ precedes the symptoms and diagnosis of connective tissue diseases[31].

\section{Limitations}

The present study is limited by the lack of data about the clinical symptoms of SARDs among the participants, so we could not compare the results obtained with any clinical manifestations. To assess the real clinical relevance of the antibodies detected, information on symptoms is necessary. Further studies should also determine the incidence of anti-DFS70 antibodies in the Polish population and their correlation with gender and clinical symptoms in patients.

In conclusion, ANA prevalence in the Polish population is similar to that observed in other highly developed countries. In the Polish population, ANA are more prevalent in women and with elderly individuals. The cut-off threshold used in the laboratory has a considerable impact on the percentage of positive results obtained. In order to reduce the number of positive results released, we suggest that Polish laboratories should set 1:160 as the cut-off threshold.

List of Abbreviations: AAb - autoantibodies; AC - anti-cell; AD - Autoimmune diseases; AMA - Antimitochondrial antibodies ANA - anti-nuclear antibody; BMI - body mass index; CFPiP - College of Family Physician in Poland DFS70 - dense fine speckled; Hep-2 - human laryngeal carcinoma cell line; ICAP - International Consensus on ANA patterns; IIFA indirect immunofluorescence assay; NAAbs - natural autoantibodies; NuMA - nuclear mitotic apparatus; PoLA - Polish Lipid Association; SARDs - Systemic Autoimmune Rheumatic Diseases; WHR - waist-hip ratio 


\section{ETHICAL APPROVAL:}

Research involving human subjects complied with all relevant national regulations, institutional policies and is in accordance with the tenets of the Helsinki Declaration (as revised in 2013), and has been approved by the Bioethical Committee of the Chamber of Physicians (No.K.B.Cz.-0018/2015).

\section{INFORMED CONSENT:}

Informed consent was obtained from all individuals included in this study.

\section{AVAILABILITY OF DATA AND MATERIALS}

The datasets generated during and/or analysed during the current study are available from the corresponding author on reasonable request.

\section{COMPETING INTERESTS}

$\mathrm{JJJ}$ and MB have received an unrestricted educational grant from Valeant, and has served as a consultant or speaker for Valeant. PK is employed by Euroimmun Polska Sp. z o.o., (Wroclaw, Poland, whose autoantibody reagents were used in the study. All others authors have not conflict of interest concerning the results of this analysis.

\section{RESEARCH FUNDING}

The present study was an initiative of the Polish Lipid Association (PoLA) and the College of Family Physician in Poland (CFPiP). The present study was funded by an unrestricted educational grant from Valeant (Warsaw, Poland). Valeant had no role in study design, data analysis, data interpretation, or writing of the report. The present study was also supported by Silesian Analytical Laboratories (SLA), CHDE, BIO-RAD, Euroimmun. 


\section{AUTHORS' CONTRIBUTIONS}

JJJ, MB designed the LIPIDOGRAM2015 study and completed the acquisition of data. PK conducted the analyses for the study and completed the first draft of the manuscript. SK made a substantial contribution to the concept of the study. PK, SK, JJJ, MB, AK, MD made a substantial contribution to the interpretation of data. All authors revised the article critically for important intellectual content. All authors gave final approval of the work have participated sufficiently in the work and take public responsibility for appropriate portions of the content.

\section{ACKNOWLEDGMENTS:}

We would like to thank all volunteer LIPIDOGRAM2015 investigators, all volunteer staff and all participants. The list of the LIPIDOGRAM 2015 investigators is at the end of the article**.

\section{**LIPIDOGRAM2015 Investigators}

Al-Shaer B., Andrusewicz W., Andrzejczuk-Rosa M., Anusz-Gaszewska E., Bagińska A., Balawajder P., Bańka G., Barańska-Skubisz E., Barbara Przyczyna B., Bartkowiak S., Bartodziej J., Bartosiewicz M., Basałyga M., Batyra A., Bąk A., Bednarz M., Bejnar K., Bernacki W., Betiuk-Kwiatkowska M., Biegaj S., Bień M., Bilski W., Biłogan M., BirutaPawłowska G. Biskup A., Błaszczyk B., Błaszczyk H., Błońska-Jankowska T., BogackaGancarczyk B., Bojanowska M., Bonda E., Borowik-Skwarek J., Borowska J., Bruckner J., Brzostek J., Brzuchacz M., Budzyńska M., Bulzacka-Fugiel I., Bulzak J., Bunikowski K., Cebulska A., Celka T., Cempel-Nowak E., Chechliński W., Chludzińska A., Chmiel D., Chmielewska M., Cichy M., Ciemięga A., Ciepluch A., Cieszyńska I., Czajka B., Czapla B., Czerner M., Czerwińska B., Czuryszkiewicz W., Daleka E., Dawid Z., Dąbrowska M., Dąbrowska R., Dąbrowski D., Dąbrowski M., Demczyszyn K., Dębowska-Serwińska A., Dmochowski J., Dobrzecka-Kiwior J., Dolanowska E., Dolanowski H., Dołek P., Domagała 
M., Domański H., Doszel A., Duda D., Dudkowska M., Dudziuk B., Dybciak P., Dymanowski M., Dziadzio-Bolek L., Eicke M., El-Hassan H., Eremus A., Fąferek-Muller M., FiguraRoguska E., Fijałkowska-Kaczmarek I., Flis M., Florczak T., Florczuk M., Foryszewska-Witan E., Frydrych W., Fugiel A., Futyma E., Gaca-Jaroszewicz A., Gajdamowicz I., Ganczarski K., Gatnar A., Gers M., Głowacki A., Głód K., Godula J., Gołąb J., Gołębiewski M., Goszczyńska E., Gościcka K., Górna-Hajduga A., Górny E., Grabowska T., Grabowski R., Graczyk-Duda A., Gromow A., Grudewicz A., Gruszecka J., Gruszka A., Gryboś J., Grzebyk J., Grzechowiak A., Grzesiak D., Grześkowiak T., Guźla A., Hachuła G., Hawel B., Hiltawska H., Honkowicz E., Ignatowicz J., Imielski K., Iwaniura A., Jagieła-Szymala A., Jalć-Sowała M., Janczylik A., Janisz E., Janiszek M., Jankiewicz-Ziobro K., Januszewska K., Jaremek A., Jaros-Urbaniak A., Jarosz J., Jarosz P., Jasiński W., Jezierska-Wasilewska M., Jędraszewski T., Jędrzejowska A., Józefowicz R., Juźwin K., Kacprzak E., Kaczmarek-Szewczyk J., Kaczmarzyk M., Kandziora R., Kaniewski C., Karolak-Brandt L., Kasperczyk S., Kasperek-Dyląg E., Kedziora I., Kępa A., Kiciński J., Kielak-Al-Hosam J., Kiełczawa Ł., Kilimowicz P., Kitliński K., Kiwka T., Klein U., Klichowicz L., Klimowicz A., Klonowski B., Kmolek B., Kobyłko-Klepacka E., Kocoń A., Kolenda A., Kollek E., Kopeć M., Koper-Kozikowska B., Koralewska J., Korczyńska M., Korzeniewski M. T., Kosk A., Kotarski K., Kowalczyk E., Kowalczyk M., Kowalik I., KozakBłażkiewicz B., Kozik M., Kozłowska D., Kozłowska E., Kozłowska M., Kozubski T., Kózka K., Kraśnik L., Krężel T., Krochmal B., Król B., Król G., Król J., Królikowska T., Kruszewska H., Krygier-Potrykus B., Krystek W., Krzysztoń J., Kubicki T., Kuczmierczyk-El-Hassan A., Kuczyńska-Witek W., Kujda D., Kurowski A., Kurzelewska-Solarz I., Kwaczyńska M., Kwaśniak M., Kwaśniak P., Kwietniewska T., Łebek-Ordon A., Lebiedowicz A., LejkowskaOlszewska L., Lentas M., Lesiewicz-Ksycińska A., Limanowski M., Łoniewski S., Łopata J. A., Łubianka B., Łukasiuk I., Łużna M., Łysiak M., Łysik B., Machowski Z., MaciaczykKubiak J., Mackiewicz-Zabochnicka G. Magner-Krężel Z., Majda S., Malinowski P., Mantyka 
J., Marchlik E., Martyna-Ordyniec G., Marzec J., Marzec M., Matejko-Wałkiewicz R., Mazur M., Michalczak M., Michalska-Żyłka A., Michniewicz M.,Mika-Staniszewska D., Mikiciuk E., Mikołajczak T., Milewski J., Miller E., Misiaszek B., Mizik-Łukowska M., MłyńczykPokutycka E., Mocek M., Moczała M., Morawska-Hermanowicz M., Moryc P., Moskal A., Moskal S., Moździerz A., Moździerz P., Mrozińska M., Mrozowicz K., Mróz G. Munia T., Mura A., Muras-Skudlarska M., Murawska E. Z., Murawski Ł., Murawski R., Musielak R., Nadaj K., Nagarnowicz W., Napierała R., Niedźwiecka M., Niemirski A., Nikiel J., Nosal M., Nowacki W., Nowak J., Nyrka M., Obst A., Ochowicz J., Ogonowska E., Oleszczyk M., Ołdakowski A., Ołowniuk-Stefaniak I., Ordowska-Rejman J., Orliński M., Osińska B., Ostańska-Burian A., Paciorkowska A., Paczkowska U., Paluch L., Pałka L., PaszkoWojtkowska J., Paszkowska A., Pawlak-Ganczarska E., Pawlik W., Pawłowska I., Paździora M., Permiakow G. Petlic-Marendziak A., Piasecka T., Piaścińska E., Piktel A., PilarskaIgielska A., Piotrkowska A., Piwowar-Klag K., Planer M., Plewa J., Płatkiewicz P., Płonczyńska B., Podgórska A., Polewska M., Porębska B., Porwoł P., Potakowska I., Prokop A., Przybylski J., Przybyła M., Psiuk H., Ptak K., Puzoń G. Rabiza N., Rachwalik S., Raczyńska E., Raniszewska M., Romanek-Kozik A., Rosa A., Rosa K., Rozewicz A., Rudzka-Kałwak J., Rusak J., Rutkowska D., Rybacki M., Rybińska D., Rycyk-Sadowska A., Rynda L., Rynkiewicz B., Sadowska-Krawczyk B., Sadowska-Zarzycka M., Sarnecka B., SawalachTomanik E., Sidor-Drozd B., Siemieniak-Dębska M., Sieroń A., Siewniak-Zalewska B., Sikora A., Sitarska-Pawlina B., Skorupski J., Skrzypińska-Mansfeld I., Skubisz J., Skwarek R., Słodyczka M., Smentek M., Smolińska K., Solarz B., Sosnowska W., Sroka B., Stachura H., Stangreciak D., Staniak M., Stańczyk Z., Stańszczak-Ozga D., Startek E., Stefańczyk M., Stelmach R., Sternadel-Rączka E., Sternik M., Stępień J., Stocka J., Stokowska-Wojda M., Studler-Karpińska M., Suchorukow W., Sufryd W., Supłacz B., Sygacz J., Szczepański Ł., Szkandera J., Szłapa-Zellner J., Szydlarska D., Śliwa T., Śliwka J., Śmiejkowski Ł., Targońska 
A., Tesarska E., Tobiasz M., Tomaka J., Tomalska-Bywalec K., Tomiak E., Topczewski S., Trawińska A., Trela-Mucha L., Trojanowski D., Trzaskowska M., Trzcińska-Larska B., Trznadel-Mozul A., Ulanicka-Liwoch K., Urbanowicz M., Uthke-Kluzek A., Waczyński J., Walczak J., Warsz L., Wasyńczuk M., Wąchała-Jędras U., Wąsowicz D., Wczysła J., Wenda F., Werner-Kubicka E., Weryszko E., Węgrzynowska B., Wiaksa M., Wiankowski M., Wicherek A., Wieczorek R., Wiencek R., Wienzek-Tatara G., Wierzbicka B., Wierzbicki M., Wilczyńska B., Wilmańska D., Winiarski P., Wiszniewska-Pabiszczak A., Witkowska M. B., Witzling J., Wlaź A., Wojtkowiak I., Woydyłło J., Woźniak K., Wójtowicz A., Wrona J., Wrońska M., Wujkowska H., Wyrąbek J., Wysokiński O., Zakrzewski R., Zaleska-Zatkalik J., Zaleski J., Zalewska- Dybciak M., Zalewska E., Zalewska-Uchimiak B., Zawadzka-Krajewska J., Zawadzki J., Zieliński A., Zubrycka E., Żybort I., Żymełka M.

\section{REFERENCES}

1. Hayter SM, Cook MC. Updated assessment of the prevalence, spectrum and case definition of autoimmune disease. Autoimmunity Reviews. 2012. https://doi.org/10.1016/j.autrev.2012.02.001

2. Tan EM, Feltkamp TEW, Smolen JS, Butcher B, Dawkins R, Fritzler MJ, et al. Range of antinuclear antibodies in "healthy" individuals. Arthritis Rheum. 1997;40(9):160111. https://doi.org/10.1002/art.1780400909

3. Nilsson BO, Skogh T, Ernerudh J, Johansson B, Löfgren S, Wikby A, et al. Antinuclear antibodies in the oldest-old women and men. J Autoimmun. 2006; https://doi.org/10.1016/j.jaut.2006.10.002 
4. Akmatov MK, Röber N, Ahrens W, Flesch-Janys D, Fricke J, Greiser H, et al. Antinuclear autoantibodies in the general German population: prevalence and lack of association with selected cardiovascular and metabolic disorders-findings of a multicenter population-based study. Arthritis Res Ther. 2017;19(1):127. http://arthritisresearch.biomedcentral.com/articles/10.1186/s13075-017-1338-5

5. Ngo ST, Steyn FJ, McCombe PA. Gender differences in autoimmune disease. Front Neuroendocrinol. 2014;35(3):347-69. http://dx.doi.org/10.1016/j.yfrne.2014.04.004

6. Agmon-Levin N, Damoiseaux J, Kallenberg C, Sack U, Witte T, Herold M, et al. International recommendations for the assessment of autoantibodies to cellular antigens referred to as anti-nuclear antibodies. Ann Rheum Dis. 2014;73(1):17-23. https://ard.bmj.com/lookup/doi/10.1136/annrheumdis-2013-203863

7. Shiff NJ, Lix LM, Joseph L, Duffy C, Tucker LB, Svenson LW, et al. The prevalence of systemic autoimmune rheumatic diseases in Canadian pediatric populations: administrative database estimates. Rheumatol Int. 2015;35(3):569-73. http://link.springer.com/10.1007/s00296-014-3136-6

8. Aygün E, Kelesoglu FM, Dogdu G, Ersoy A, Basbug D, Akça D, et al. Antinuclear antibody testing in a Turkish pediatrics clinic: is it always necessary? Pan Afr Med J. 2019;32. http://www.panafrican-med-journal.com/content/article/32/181/full/

9. Przywara-Chowaniec B, Seget S, Dróżdż M, Puzio A, Czuba Z, Nowalany-Kozielska E, et al. Ocena stanu antyoksydacyjnego w wybranych chorobach układowych tkanki łącznej. Ann Acad Medicae Silesiensis. 2018;72:116-20. http://annales.sum.edu.pl/archiwum_publikacje/16_2018.pdf

10. Kannan S. Free radical theory of autoimmunity. Theor Biol Med Model. 2006;3:1-16. https://tbiomed.biomedcentral.com/articles/10.1186/1742-4682-3-22 
11. Salihoglu S, Dogan SC, Kavakci O. Effects of childhood psychological trauma on rheumatic diseases. Eur J Rheumatol. 2019;6(3):126-9.

https://eurjrheumatol.org//en/effects-of-childhood-psychological-trauma-on-rheumaticdiseases- 133226

12. Fischer K, Brzosko I, Brzosko M. Autoprzeciwciała w praktyce reumatologicznej Autoantibodies in rheumatology practice. 2016;(1):39-50.

https://journals.viamedica.pl/forum_reumatologiczne/article/download/43331/31247

13. Mariz HA, Sato EI, Barbosa SH, Rodrigues SH, Dellavance A, Andrade LEC. Pattern on the antinuclear antibody-HEp-2 test is a critical parameter for discriminating antinuclear antibody-positive healthy individuals and patients with autoimmune rheumatic diseases. Arthritis Rheum. 2011;63(1):191-200.

http://doi.wiley.com/10.1002/art.30084

14. Zavdy O, Shoenfeld Y, Amital H. Natural Autoantibodies-Homeostasis, Autoimmunity, and Therapeutic Potential. In: Autoantibodies. Elsevier; 2014. p. 2133. https://linkinghub.elsevier.com/retrieve/pii/B9780444563781000034

15. Atassi MZ, Casali P, Atassi MZ, Casali P. Molecular mechanisms of autoimmunity. Autoimmunity. 2008;41(2):123-32. http://www.tandfonline.com/doi/full/10.1080/08916930801929021

16. Avrameas S, Alexopoulos H, Moutsopoulos HM. Natural Autoantibodies: An Undersugn Hero of the Immune System and Autoimmune Disorders-A Point of View. Front Immunol. 2018;9(JUN):1-4. https://www.frontiersin.org/article/10.3389/fimmu.2018.01320/full

17. Lleo A, Invernizzi P, Gao B, Podda M, Gershwin ME. Definition of human autoimmunity - autoantibodies versus autoimmune disease. Autoimmun Rev. 
2010;9(5):A259-66. https://linkinghub.elsevier.com/retrieve/pii/S1568997209002018

18. Guo Y-P, Wang C-G, Liu X, Huang Y-Q, Guo D-L, Jing X-Z, et al. The Prevalence of Antinuclear Antibodies in the General Population of China: A Cross-Sectional Study. Curr Ther Res. 2014;76:116-9.

https://linkinghub.elsevier.com/retrieve/pii/S0011393X14000150

19. Prüßmann J, Prüßmann W, Recke A, Rentzsch K, Juhl D, Henschler R, et al. Cooccurrence of autoantibodies in healthy blood donors. Exp Dermatol. 2014;23(7):51921. http://doi.wiley.com/10.1111/exd.12445

20. Satoh M, Chan EKL, Ho LA, Rose M, Parks CG, Cohn RD, et al. Prevalence and sociodemographic correlates of antinuclear antibodies in the United States.

2012;64(7):2319-27. http://doi.wiley.com/10.1002/art.34380

21. Grygiel-Górniak B, Rogacka N, Puszczewicz M. Antinuclear antibodies in healthy people and non-rheumatic diseases - diagnostic and clinical implications.

Reumatologia/Rheumatology. 2018;56(4):243-8.

https://www.termedia.pl/doi/10.5114/reum.2018.77976

22. Wandstrat A, Carr-Johnson F, Branch V, Gray H, Fairhurst A, Reimold A, Karp D, Wakeland E ON. Autoantibody profiling to identify individuals at risk for systemic lupus erythematosus. J Autoimmun. 2006;27(3):153-60. https://linkinghub.elsevier.com/retrieve/pii/S089684110600076X

23. Didier K, Bolko L, Giusti D, Toquet S, Robbins A, Antonicelli F, et al. Autoantibodies Associated With Connective Tissue Diseases: What Meaning for Clinicians? Front Immunol. 2018;9(MAR):1-20.

http://journal.frontiersin.org/article/10.3389/fimmu.2018.00541/full 
24. Jóźwiak JJ, Kasperczyk S, Tomasik T, Osadnik T, Windak A, Studziński K, et al. Manuscript body Design and rationale of a nationwide screening analysis from the LIPIDOGRAM2015 and LIPIDOGEN2015 study. Arch Med Sci. 2020;16(5):1-13. https://doi.org/10.5114/aoms.2020.96052

25. Damoiseaux J, Andrade LEC, Carballo OG, Conrad K, Francescantonio PLC, Fritzler MJ, et al. Clinical relevance of HEp-2 indirect immunofluorescent patterns: the International Consensus on ANA patterns (ICAP) perspective. Ann Rheum Dis. 2019;78(7):879-89. https://ard.bmj.com/lookup/doi/10.1136/annrheumdis-2018214436

26. WHO/Europe | Nutrition - Body mass index - BMI [Internet]. http://www.euro.who.int/en/health-topics/disease-prevention/nutrition/a-healthylifestyle/body-mass-index-bmi

27. Nishida C, Ko GT, Kumanyika S. Body fat distribution and noncommunicable diseases in populations: Overview of the 2008 WHO Expert Consultation on Waist Circumference and Waist-Hip Ratio. Vol. 64, European Journal of Clinical Nutrition. 2010. p. 2-5. http://www.nature.com/articles/ejen2009139

28. Shovman O, Gilburd B, Chayat C, Amital H, Langevitz P, Watad A, et al. Prevalence of anti-DFS70 antibodies in patients with and without systemic autoimmune rheumatic diseases. Clin Exp Rheumatol. 2018;36(1):121-6. https://www.clinexprheumatol.org/article.asp?a=11737

29. Miyara M, Albesa R, Charuel J-L, El Amri M, Fritzler MJ, Ghillani-Dalbin P, et al. Clinical Phenotypes of Patients with Anti-DFS70/LEDGF Antibodies in a Routine ANA Referral Cohort. Clin Dev Immunol. 2013;2013:1-8. http://www.hindawi.com/journals/jir/2013/703759/ 
30. Kwiatkowska Brygida RF, Maślińska Maria, Kłak Anna GJ, Piotr S-K. Wczesna diagnostyka chorób reumatycznych - ocena obecnej sytuacji i rekomendacje zmian. National Institute of Geriatrics, Rheumatology and Rehabilitation; 2015.

31. Jonsson R. Autoantibodies Present Before Symptom Onset in Primary Sjögren Syndrome. JAMA. 2013;310(17):1854.

http://jama.jamanetwork.com/article.aspx?doi=10.1001/jama.2013.278448 
Table 1. Characteristics of the population.

\begin{tabular}{|l|c|c|c|c|c|c|}
\hline & \multicolumn{2}{|c|}{ All } & \multicolumn{2}{c|}{ Male } & \multicolumn{2}{c|}{ Female } \\
& \multicolumn{2}{|c|}{ n=1731 } & \multicolumn{2}{c|}{ n=688 } & \multicolumn{2}{c|}{ n=1043 } \\
\cline { 2 - 7 } & Mean & SD & Mean & SD & Mean & SD \\
\hline Age & 51.0 & 13.0 & 50.4 & 13.1 & 51.6 & 12.9 \\
\hline Height (cm) & 168 & 9.15 & 177 & 6.71 & 163 & 6.05 \\
\hline Weight (kg) & 80.2 & 17.1 & 91.2 & 15.2 & 73.0 & 14.1 \\
\hline BMI (kg/cm ${ }^{2}$ ) & 28.2 & 5.05 & 29.3 & 4.50 & 27.5 & 5.29 \\
\hline Waist circumference (cm) & 94 & 14.3 & 101 & 12.0 & 89.3 & 13.6 \\
\hline Hips circumference (cm) & 105 & 10.8 & 105 & 9.33 & 105 & 11.7 \\
\hline WHR & 0.89 & 0.09 & 0.96 & 0.07 & 0.85 & 0.07 \\
\hline
\end{tabular}

WHR - waist-hip ratio; BMI - body mass index 
Table 2. Frequency distribution of ANA patterns.

\begin{tabular}{|c|c|c|}
\hline ICAP Pattern & $\begin{array}{c}\text { Number } \\
n=260\end{array}$ & $\%$ \\
\hline AC-1 - Homogenous & 10 & $3.85 \%$ \\
\hline AC-2 - Dense Fine speckled & 130 & $50.00 \%$ \\
\hline AC-3-Centromere & 3 & $1.15 \%$ \\
\hline AC4/AC5 - Fine/Large/Coarse Speckled & 38 & $14.62 \%$ \\
\hline AC6/AC7 - Multiple/Few Nuclear Dots & 3 & $1.15 \%$ \\
\hline AC-8 - Homogenous Nucleolar & 1 & $0.38 \%$ \\
\hline AC-9/AC-10 - Clumpy/Punctate Nucleolar & 28 & $10.77 \%$ \\
\hline AC11/AC12 - Smooth/Punctate Nuclear envelope & 2 & $0.77 \%$ \\
\hline AC-15 - Fibrillar Linear & 6 & $2.31 \%$ \\
\hline AC-16 - Fibrillar Filamentous & 4 & $1.54 \%$ \\
\hline AC-19/AC-20 - Dense Fine/Fine Speckled & 6 & $2.31 \%$ \\
\hline AC-21- Reticular/AMA & 40 & $15.38 \%$ \\
\hline AC-23 - Rods and Rings & 3 & $1.15 \%$ \\
\hline AC-25/AC-26 - Spindle Fibers/NuMA-like & 4 & $1.54 \%$ \\
\hline AC-27 - Intercellular Bridge & 2 & $0.77 \%$ \\
\hline AC-28 - Mitotic Chromosomal & 1 & $0.38 \%$ \\
\hline
\end{tabular}

AC - anti-cell; AMA - Antimitochondrial antibodies; ICAP - International Consensus on ANA patterns; NuMA - nuclear mitotic apparatus 
Table 3. Titers and types of autoantibody staining depending on gender.

\begin{tabular}{|c|c|c|c|c|c|}
\hline & \multicolumn{2}{|c|}{ Male } & \multicolumn{2}{|c|}{ Female } & \multirow{3}{*}{$P$ value } \\
\hline & \multicolumn{2}{|c|}{$n=688$} & \multicolumn{2}{|c|}{$n=1043$} & \\
\hline & percentage & number & percentage & number & \\
\hline ANA titer 1:100 & $10.6 \%$ & 73 & $17.9 \%$ & 187 & $<0.001$ \\
\hline ANA titer 1:160 & $5.4 \%$ & 37 & $10.3 \%$ & 107 & $<0.001$ \\
\hline ANA titer 1:320 & $1.7 \%$ & 12 & $4.5 \%$ & 47 & 0.001 \\
\hline ANA titer 1:640 & $0.6 \%$ & 4 & $1.9 \%$ & 20 & 0.020 \\
\hline ANA titer 1:1000 & $0.1 \%$ & 1 & $0.6 \%$ & 6 & 0.168 \\
\hline AC-1 Homogenous & $0.4 \%$ & 3 & $0.7 \%$ & 7 & 0.528 \\
\hline AC-2 Dense Fine speckled & $4.4 \%$ & 30 & $9.6 \%$ & 100 & $<0.001$ \\
\hline AC-3 Centromere & $0.1 \%$ & 1 & $0.2 \%$ & 2 & 0.820 \\
\hline $\begin{array}{l}\text { AC4/AC5 Fine/Large/Coarse } \\
\text { Speckled }\end{array}$ & $0.7 \%$ & 5 & $3.2 \%$ & 33 & 0.001 \\
\hline $\begin{array}{l}\text { AC6/AC7 Multiple/Few Nuclear } \\
\text { Dots }\end{array}$ & $0.1 \%$ & 1 & $0.2 \%$ & 2 & 0.820 \\
\hline AC-8 Homogenous Nucleolar & $0.1 \%$ & 1 & $0.0 \%$ & 0 & 0.218 \\
\hline $\begin{array}{l}\text { AC-9/AC-10 Clumpy/Punctate } \\
\text { Nucleolar }\end{array}$ & $2.5 \%$ & 17 & $1.1 \%$ & 11 & 0.022 \\
\hline $\begin{array}{l}\text { AC11/AC12 Smooth/Punctate } \\
\text { Nuclear envelope }\end{array}$ & $0.1 \%$ & 1 & $0.1 \%$ & 1 & 0.767 \\
\hline AC-15 Fibrillar Linear & $0.6 \%$ & 4 & $0.2 \%$ & 2 & 0.177 \\
\hline AC-16 Fibrillar Filamentous & $0.1 \%$ & 1 & $0.3 \%$ & 3 & 0.547 \\
\hline
\end{tabular}




\begin{tabular}{|l|c|c|c|c|c|}
\hline AC-19/AC-20 Dense Fine/Fine & $0.4 \%$ & 3 & $0.3 \%$ & 3 & 0.607 \\
Speckled & & & & & \\
\hline AC-21 Reticular/AMA & $1.6 \%$ & 11 & $2.8 \%$ & 29 & 0.109 \\
\hline AC-23 Rods and Rings & $0.1 \%$ & 1 & $0.2 \%$ & 2 & 0.820 \\
\hline AC-25/AC-26 Spindle & $0.0 \%$ & 0 & $0.4 \%$ & 4 & 0.104 \\
Fibers/NuMA-like & & & & & 0.082 \\
\hline AC-27 Intercellular Bridge & $0.3 \%$ & 2 & $0.0 \%$ & 0 & 0.417 \\
\hline AC-28 Mitotic Chromosomal & $0.0 \%$ & 0 & $0.1 \%$ & 1 & \\
\hline
\end{tabular}

AC - anti-cell, ANA - anti-nuclear antibody; AMA - Antimitochondrial antibodies; ICAP -

International Consensus on ANA patterns; NuMA - nuclear mitotic apparatus 
Table 4. Characteristics of the population based on occurrence of ANA.

\begin{tabular}{|c|c|c|c|c|c|c|}
\hline & \multicolumn{2}{|c|}{ ANA negative } & \multicolumn{2}{|c|}{ ANA positive } & \multirow{2}{*}{ change } & \multirow{3}{*}{$P$ value } \\
\hline & \multicolumn{2}{|c|}{$n=1471$} & \multicolumn{2}{|c|}{$n=260$} & & \\
\hline & Mean/\% & $\mathrm{SD} / \mathrm{n}$ & Mean/\% & $\mathrm{SD} / \mathrm{n}$ & & \\
\hline Genders (\% of men) & $42 \%$ & & $28 \%$ & & & $<0.001$ \\
\hline Age (years) & 51 & 13 & 54 & 12 & $6 \%$ & $<0.001$ \\
\hline Height (cm) & 169 & 9.2 & 166 & 8.3 & $-1 \%$ & $<0.001$ \\
\hline Weight (kg) & 80.7 & 17.2 & 77.6 & 16.2 & $-4 \%$ & 0.008 \\
\hline BMI $\left(\mathrm{kg} / \mathrm{cm}^{2}\right)$ & 28.2 & 5.05 & 28.0 & 5.11 & $-1 \%$ & 0.513 \\
\hline $\begin{array}{l}\text { Waist circumference } \\
\text { (cm) }\end{array}$ & 94.1 & 14.4 & 93.0 & 13.6 & $-1 \%$ & 0.257 \\
\hline $\begin{array}{l}\text { Hip circumference } \\
\text { (cm) }\end{array}$ & 105.0 & 10.8 & 105.6 & 11.1 & $1 \%$ & 0.381 \\
\hline WHR & 0.90 & 0.09 & 0.88 & 0.08 & $-2 \%$ & 0.013 \\
\hline $\begin{array}{l}\text { Chronic kidney } \\
\text { disease }\end{array}$ & $2.7 \%$ & 40 & $1.5 \%$ & 4 & & 0.265 \\
\hline $\begin{array}{l}\text { Coronary artery } \\
\text { disease }\end{array}$ & $10.3 \%$ & 152 & $11.2 \%$ & 29 & & 0.690 \\
\hline Myocardial infarction & $4.1 \%$ & 61 & $4.2 \%$ & 11 & & 0.950 \\
\hline Ischemic stroke & $1.5 \%$ & 22 & $1.9 \%$ & 5 & & 0.608 \\
\hline Haemorrhagic stroke & $0.3 \%$ & 4 & $0.4 \%$ & 1 & & 0.755 \\
\hline Atrial fibrillation & $2.8 \%$ & 41 & $4.2 \%$ & 11 & & 0.209 \\
\hline Dyslipidemia & $49.4 \%$ & 726 & $51.9 \%$ & 135 & & 0.445 \\
\hline
\end{tabular}




\begin{tabular}{|l|c|c|c|c|c|c|}
\hline Family & & & & & & 0.249 \\
\hline Dypercholesterolemia & $3.7 \%$ & 55 & $2.3 \%$ & 6 & & \\
\hline Arterial hypertension & $42.1 \%$ & 619 & $47.7 \%$ & 124 & & 0.092 \\
\hline Healthy individuals & $36.3 \%$ & 534 & $38.1 \%$ & 99 & & 0.584 \\
\hline
\end{tabular}

ANA - anti-nuclear antibodies; WHR - waist-hip ratio; BMI - body mass index 
Table 5. Characteristics of the population based on age in the occurrence of ANA (* comparison male vs female dependent on age).

\begin{tabular}{|c|c|c|c|c|c|c|c|c|c|c|}
\hline & \multicolumn{3}{|c|}{ All } & \multicolumn{3}{|c|}{ Male } & \multicolumn{3}{|c|}{ Female } & \multirow[b]{2}{*}{$\begin{array}{l}\text { P value } \\
\text { (gender) }\end{array}$} \\
\hline Age & $\begin{array}{c}\text { Number } \\
\text { of } \\
\text { individuals }\end{array}$ & $\begin{array}{c}\text { Number } \\
\text { positive } \\
\text { ANA }\end{array}$ & \begin{tabular}{|c|} 
Percentage \\
positive \\
ANA
\end{tabular} & $\begin{array}{c}\text { Number } \\
\text { of } \\
\text { individuals }\end{array}$ & $\begin{array}{c}\text { Number } \\
\text { positive } \\
\text { ANA }\end{array}$ & $\begin{array}{l}\text { Percentage } \\
\text { positive } \\
\text { ANA }\end{array}$ & \begin{tabular}{|c|}
$\begin{array}{c}\text { Number } \\
\text { of } \\
\text { individuals }\end{array}$ \\
\end{tabular} & $\begin{array}{c}\text { Number } \\
\text { positive } \\
\text { ANA }\end{array}$ & $\begin{array}{c}\text { Percentage } \\
\text { positive } \\
\text { ANA }\end{array}$ & \\
\hline$<30$ & 127 & 10 & $7.9 \%$ & 52 & 2 & $3.8 \%$ & 75 & 8 & $10.7 \%$ & 0.143 \\
\hline $30-40$ & 227 & 31 & $13.7 \%$ & 100 & 8 & $8.0 \%$ & 127 & 23 & $18.1 \%$ & 0.024 \\
\hline $40-50$ & 380 & 52 & $13.7 \%$ & 151 & 19 & $12.6 \%$ & 229 & 33 & $14.4 \%$ & 0.610 \\
\hline $50-60$ & 555 & 74 & $13.3 \%$ & 221 & 17 & $7.7 \%$ & 334 & 57 & $17.1 \%$ & 0.001 \\
\hline $60-70$ & 344 & 71 & $20.6 \%$ & 129 & 22 & $17.1 \%$ & 215 & 49 & $22.8 \%$ & 0.203 \\
\hline$>70$ & 98 & 22 & $22.4 \%$ & 35 & 5 & $14.3 \%$ & 63 & 17 & $27.0 \%$ & 0.138 \\
\hline $\begin{array}{c}\text { P value } \\
\text { (age) } \\
\text { All }\end{array}$ & \multicolumn{3}{|c|}{0.001} & \multicolumn{3}{|c|}{0.035} & \multicolumn{3}{|c|}{0.038} & $0.038^{*}$ \\
\hline
\end{tabular}

ANA - anti-nuclear antibodies 
Figure 1. Frequency analysis comparing the $1: 100$ and $1: 160$ groups $(n=260)$ in terms of final ANA titer

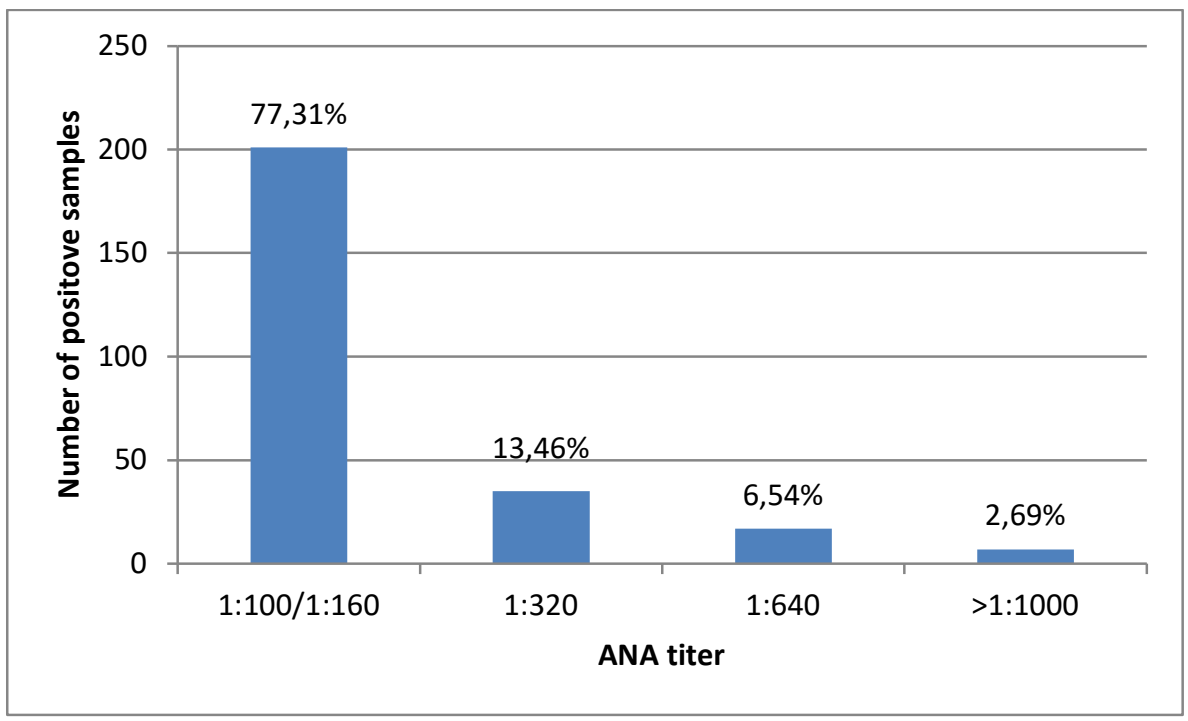


Figures

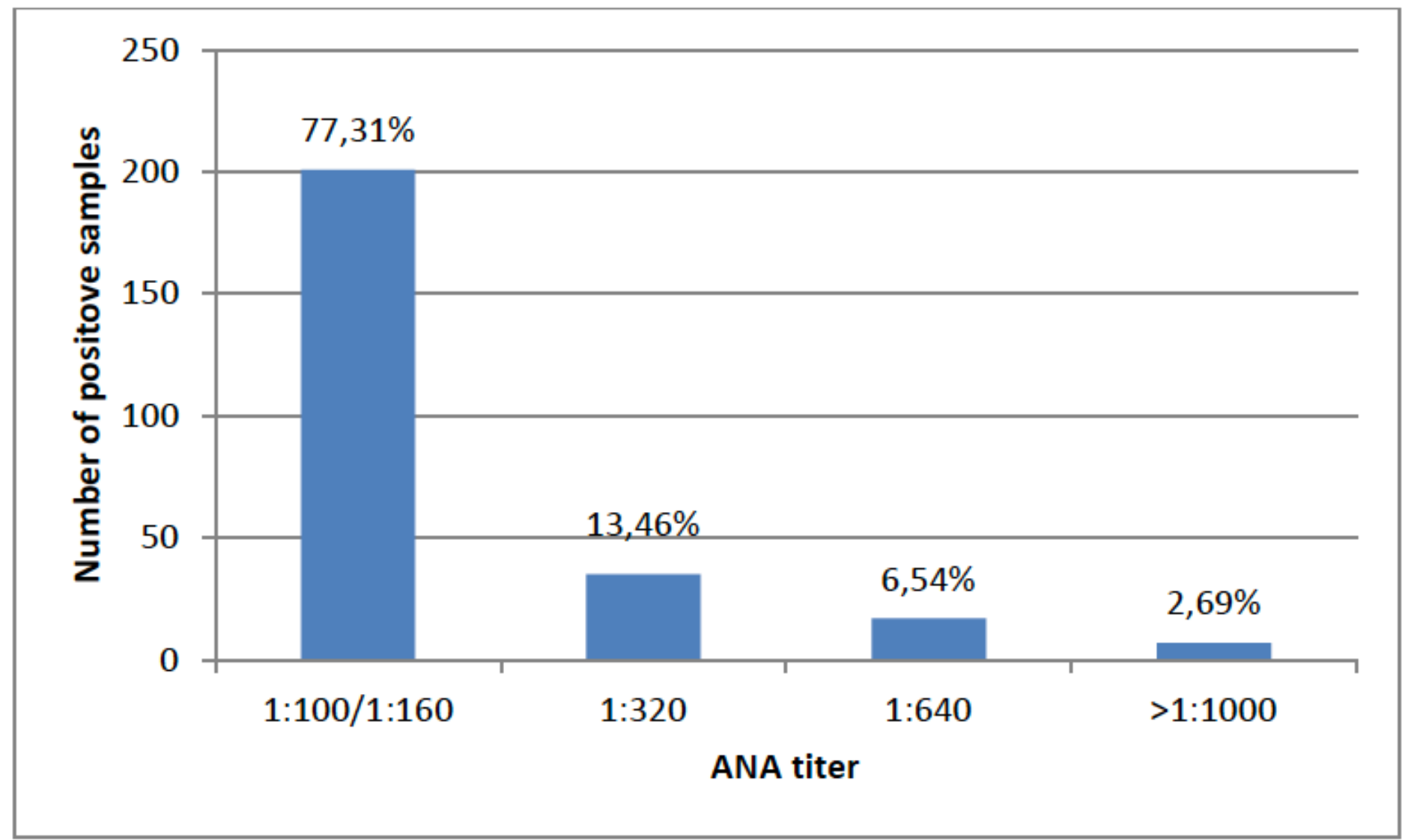

Figure 1

Frequency analysis comparing the 1:100 and 1:160 groups $(n=260)$ in terms of final ANA titer 